\title{
URGENSI SAKSI PELAKU YANG BEKERJASAMA (JUSTICE COLLABORATOR) DALAM TINDAK PIDANA KORUPSI
}

\author{
Ni Luh Made Dwi Pusparini, A. A. Sagung Laksmi Dewi, I Made Minggu Widyantara \\ Fakultas Hukum Universitas Warmadewa, Denpasar - Bali, Indonesia \\ dwipusparini17@gmail.com
}

\begin{abstract}
Abstrak
Negara Indonesia merupakan Negara Hukum jadi kekuasaan Negara dijalankan menurut hukum yang berlaku sehingga hukum tersebut berlaku bagi semua aspek kehidupan bermasyarakat yang menuju pada terciptanya suatu tujuan dari hukum tersebut. Akibat lemahnya hukum di Negara Indonesia masih berkembangnya banyak kejahatan yang terjadi, tindak pidana korupsi yang termasuk kejahatan terorganisir. Tidak saja di Negara Indonesia, kejahatan korupsi juga banyak berkembang di Negara lain. Akibatnya, dalam menanggulangi terjadinya tindak pidana korupsi diperlukan adanya pelaku yang bekerjasama sebagai saksi dengan pihak penegak hukum dalam hal mengungkap pelaku utama dan lainnya sehingga berpengaruh besar pada perkara korupsi itu. Dengan metode penelitian hukum normatif, penelitian ini menelaah urgensi pengaturan saksi pelaku yang bekerjasama dalam tindak pidana korupsi dan sanksi pidana terhadap saksi pelaku yang bekerjasama dalam tindak pidana korupsi. Hasil menunjukkan dalam hukum positif Indonesia terdapat peraturan tentang Justice Collaborator di Peraturan Pemerintah No 71 Pasal 5 Ayat (2) Tahun 2000 mengatur mengenai hak serta perlindungan hukum bagi setiap saksi, pelapor tindak pidana/ saksi yang melapor. Sedangkan pertimbangan hakim dalam menjatuhkan sanksi pidana terhadap justice collaborator dalam tindak pidana korupsi yang unsurnya berdasarkan UU No. 20 tahun 2001 terkait UU No 31 tahun 1999 mengenai pemberantasan perkara korupsi serta terdapat dalam Surat Edaran Mahkamah Agung No 4 tahun 2011 dalam tindakan khusus mengenai sanksi pidana yaitu memberikan keringanan bentuk perlindungan lain.
\end{abstract}

Kata kunci: Justice Collaborator; Korupsi; Tindak Pidana,

\begin{abstract}
The State of Indonesia appears as a State of Law meaning that State power is exercised according to applicable laws so the law applies to all aspects of social life that lead to the creation of an objective of the law. As a consequence of the weakness of the law in the State of Indonesia there are still a large number of crimes that are developing, including the criminal acts of corruption as one of organized crimes. Not only have corruption crimes developed in Indonesia but also in other countries. As a result, in tackling the emergence of the criminal acts of corruption, it is necessary to have perpetrators cooperating as witnesses with law enforcement authorities in terms of revealing the main perpetrators and others so it has a major influence on the corruption case. Using the normative legal research method, this research examines the urgency of regulating witnesses of collaborating perpetrators in a the criminal act of corruption and the criminal sanctions against witnesses of collaborating perpetrators in criminal acts of corruption. The results show that in positive Indonesian law there are regulations regarding Justice Collaborator in Government Regulation No 71 Article 5 Paragraph (2) of 2000 regulating the rights and legal protection of every witness, criminal reporter / witness who reports. Whereas judges' considerations in imposing criminal sanctions on justice collaborators in the criminal acts of corruption which are based on Law No. 20 of 2001 related to Law No. 31 of 1999 concerning Eradicating Corruption Crimes and is contained in the Supreme Court Circular No. 4 of 2011 in specific actions regarding Criminal Sanctions namely providing relief in other forms of protection.
\end{abstract}

Keywords: Justice Collaborator; Corruption; Crime

\section{PENDAHULUAN}

Negara kita yaitu negara Indonesia sangat diwarnai dengan kebudayaan masyarakat maupun perkembangan ilmu hukum tentang kebijakan-kebijakan aturan yang berbeda pandangan baik fungsi hukum maupun keberadaannya sehingga penegakan hukum diperlukan kerjasama berbagai pihak termasuk juga masyarakat. Negara Indonesia merupakan salah satu negara hukum yang berarti segala 
bidang aspek kehidupan diatur dalam peraturan yang sah sehingga terciptanya tujuan hukum terdapat dalam Pasal 1 ayat 3 di UUD NRI.

Peran hakim dalam memutus perkara kepemilikan seseorang dalam mengalihkan hak tersebut, kebebasan seseorang dapat dicabut sampai dengan menghilangkan hidup seseorang yang menjadi pelaku perkara (H. Dudu, 2006). Dikarenakan Indonesia masih melemahnya hukum menjadi faktor penyebab banyaknya kejahatan yang marak terjadi salah satunya yaitu kejahatan korupsi yang bersifat terorganisir/mengelompok. Sejarah membuktikan bahwa banyak Negara yang dirundung dengan kejahatan korupsi (Prodjohamidjojo, 2002).

Dampak dari kejahatan korupsi sangat menimbulkan banyak masalah dalam kehidupan seperti membahayakan stabilitas keamanan Negara, pembangunan nasional, sosial-politik, dan ekonomi masyarakat serta dapat merusakan moral bangsa. Mengungkap kasus tindak pidana korupsi tergantung dalam alat-alat bukti yang menjadi salah satu yang sangat penting adalah keterangan dari saksi.

Salah satu cara menanggulangi tindak pidana korupsi yang bersifat terorganisir dengan adanya saksi yang bekerjasama dengan pihak penegak hukum dalam hal pengungkapan kasus tindak pidana yang dilakukannya, yang biasa diistilahkan sebagai justice collaboratorl saksi pelaku yang bekerjasama. Yang memiliki peran sangat penting adalah kasus tindak pidana tersebut dapat dituntaskan. Namun, saat ini peraturan mengenai perlindungan mengenai peran saksi di Indonesia masih lemah. Pentingnya peran saksi yang bekerjasama dalam mengungkap pelaku tindak pidana yang lebih besar pengaruhnya sehingga penulis tertarik dalam menulis jurnal tersebut.

Penelitian ini mengkaji tentang urgensi pengaturan saksi pelaku yang bekerjasama dalam tindak pidana korupsi dan sanksi pidana terhadap saksi pelaku yang bekerjasama dalam tindak pidana korupsi.

\section{METODE PENELITIAN}

Tipe penelitian yang digunakan dalam Penelitian ini adalah menggunakan tipe penelitian hukum normatif yaitu menganalisis kepustakaan berdasarkan bahan hukum yang digunakan, baik primer maupun sekunder. Sedangkan pendekatan masalah yang digunakan dalam Penelitian ini adalah pendekatan Per-undang-undangan dan pendekatan Konseptual. Pendekatan perundang-undangan ini misalnya dilakukan dengan mempelajari konsistensi/kesesuaian antara Undang-Undang Dasar dengan Undang-Undang, atau antara Undang-Undang yang satu dengan Undang-Undang yang lain. Pada kali ini, penulis mempelajari kesesuaian antara Undang-Undang Dasar Negara Republik Indonesia 1945, Kitab Undang-Undang Hukum Pidana (KUHP), Undang-Undang Nomor 8 Tahun 1981 tentang Hukum Acara Pidana, UndangUndang Nomor 31 Tahun 1999 jo Undang-Undang Nomor 20 Tahun 2001 tentang Pemberantasan Tindak Pidana Korupsi, Undang-Undang Nomor 13 Tahun 2006 tentang Perlindungan Saksi dan Korban, dan Surat Edaran Mahkamah Agung (SEMA) Nomor 4 Tahun 2011.

Sumber bahan hukum primer merupakan bahan hukum yang mempunyai kekuatan mengikat dalam penelitian ini, dalam penelitian ini yaitu:

a. Undang-Undang Dasar Negara Republik Indonesia Tahun 1945

b. Kitab Undang-Undang Hukum Pidana (KUHP)

c. Undang-Undang Nomor 8 Tahun 1981 tentang Hukum Acara Pidana

d. Undang-Undang Nomor 31 Tahun 1999 jo Undang-Undang Nomor 20 Tahun 2001 tentang Pemberantasan Tindak Pidana Korupsi

e. Undang-Undang Nomor 13 Tahun 2006 tentang Perlindungan Saksi dan Korban

f. Surat Edaran Mahkamah Agung (SEMA) Nomor 4 Tahun 2011 tentang Perlakuan bagi Pelapor Tindak Pidana (Whistle Blower) dan Saksi Pelaku yang Bekerja Sama (Justice Collaborators) dan berbagai instrumen hukum yang relavan terkait urgensi justice collaborator dalam tindak pidana korupsi

g. Putusan Nomor: 84/Pid.Sus.TPK/2018/PNMdn.

Sumber bahan hukum sekunder merupakan bahan-bahan hukum yang dapat diperoleh dari pengkajian kepustakaan yaitu dengan membaca buku-buku, jurnal-jurnal hukum, dan artikel yang berhubungan dengan Urgensi Saksi Pelaku Yang Bekerjasama (Justice Collaborator) Dalam Tindak Pidana Korupsi. Untuk memperoleh bahan-bahan hukum primer, sekunder digunakan metode pengumpulan bahan hukum lalu dikelompokan dan didokumentasikan, dicatat, dikutip, diringkas, diulas sesuai kebutuhan dengan pendekatan kualitatif. 
Menganalisis penelitian ini menggunakan teknik bersifat sistematis dengan disajikan secara deskriptif-analitis, yaitu dengan mendiskripsikan bahan hukum terlebih dahulu secara sistematis kemudian menganalisa melalui teknik analisis dengan teknik tafsiran dan menggunakan argumentasi yang bertumpuk pada logika hukum dengan deduktif-induktif.

\section{HASIL PENELITIAN DAN PEMBAHASAN}

\section{Urgensi Pengaturan Saksi Pelaku yang Bekerjasama dalam Tindak Pidana Korupsi}

KBBI urgensi memiliki makna keharusan yang mendesak dalam hal urgensi bagi justice collaborator sangat penting dalam upaya memberantas tindak pidana korupsi. Hal ini dilakukan untuk terciptanya tujuan hukum yaitu:

1. Mencapai keadilan

2. Menciptakan kemanfaatan

3. Menciptakan kepastian hukum

Dalam rangka optimalisasi penanggulangan organized crime dengan memberikan perlakuan khusus serta perlindungan bagi seseorang siapapun mengetahui/ menjadi saksi. Peran masyarakat sangat dibutuhkan peranannya dalam perlindungan hukum tersebut. Pengaturan mengenai perlindungan bagi saksi dan korban menyebutkan bahwa:

"Seorang saksi yang dibebaskan dari tuntutan pidana karena kesaksiannya dapat dijadikan pertimbangan hakim dalam penjatuhan pidana terhadap perkara yang ia lakukan."

Keberadaan justice collaborator dalam suatu kepastian hukum untuk mendapatkan perlindungan yang jelas bagi pelaku yang dinyatakan sebagai justice collaborator. Seorang justice collaborator terbukti bersalah dalam kasus yang sama maka ia tidak dapat dibebaskan dari pidana. Penguatan aturan hukum dan penguatan kompetensi bagi para penegak hukum, peran serta masyarakat dalam mengungkap tindak pidana korupsi yang pada dasarnya dilakukan pemerintah dalam pemberantasan tindak pidana korupsi. Dalam surat edaran mahkamah agung (SEMA) No 4 tahun 2011 dijadikan pedoman oleh hakim dalam mengambil keputusan dalam penjatuhan hukuman baik pengadilan tingkat pertama maupun banding. Justice collaborator juga memiliki fungsi penting di dalam proses persidangan yang akan memperkuat alat bukti dan barang bukti.

Wirjono Prodjodikoro menyatakan bahwa dalam SEMA memberikan pertolongan dalam memberikan gagasan baik pengadilan negeri ataupun pengadilan tinggi yang bersifat tidak mengikat. SEMA tersebut memberikan pertolongan kepada Pengadilan Tinggi ataupun pengadilan negeri dalam memberikan gagasan yang dimuat dalam surat edaran itu akan tetapi mereka ragu dalam menjalaninya (Mulyadi, 2015). Dalam Pasal 10 ayat 2 UU No. 13 Tahun 2006 mengenai perlindungan saksi dan korban ditentukan bahwa yang juga tersangka dan yang terjerat dalam suatu kasus tidak bisa dibebaskan dari tuntutan pidana melainkan kesaksiannya dijadikan pertimbangan hakim dalam hal meringankan penjatuhan pidana.

Dalam materi pokok yang diatur dalam UU mengenai Perlindungan saksi dan korban antara lain perlindungan mengenai hak saksi dan korban, lembaga perlindungan, tata cara pemberian perlindungan dan ketetapan mengenai pemidanaan. Pada pemerintahan orde lama hingga pemerintahan orde baru banyak maraknya kasus mengenai tindak pidana korupsi. Sehingga latar belakang munculnya beberapa aturan-aturan mengenai tindak pidana korupsi yang sudah dirasa tidak mampu menjerat pelaku kejahatan yang melakukan perkara korupsi tersebut.

Di Ensiklopedia, diberi konsep bahwa korupsi merupakan penyalahgunaan wewenang oleh para pejabat atau badan-badan Negara. Tindak pidana korupsi juga terdapat pada Pasal 2 Undang-undang No 31 Tahun 1999 jo Undang-undang No 20 Tahun 2001, memberikan pengertian bahwa tindak pidana korupsi merupakan tindakan melawan hukum yang merugikan keuangan negara untuk memperkaya diri atau suatu badan.

Tindak pidana ekonomi juga banyak dilakukan oleh pemangku jabatan dan kepentingan baik di sektor publik maupun privat, tetapi merugikan keuangan negara serta pelanggaran terhadap hak-hak masyarakat merupakan tindakan korupsi (Hartanti, 2009).

Adapun jenis-jenis tindak pidana korupsi yaitu:

- Tindak pidana yang merugikan keuangan Negara

- Suap

- Pemerasan 
- Penyerobotan

- Gratifikasi

Sifat- sifat dari korupsi ialah korupsi yang sepintas kelihatannya bermotif politik dan bermotifkan mendapatkan uang tetapi sesungguhnya bermotif lain. Sedangkan, ciri-ciri korupsi tersebut yaitu:

1) melibatkan lebih dari satu individu;

2) dilakukan dengan rahasia;

3) keuntungan timbal balik;

4) menyelubungi perbuatan dengan berlindung dibalik hukum;

5) memberikan keputusan tegas demi mempengaruhi keputusan; dan

6) penipuan serta penghianatan terhadap kepercayaan.

Jika membicarakan mengenai faktor-faktor penyebab korupsi adalah banyak tetapi jika faktor utama menurut penulis menjadi hal utama terlihat dari segi ekonomi dimana pendapatan seseorang tidak mencukupi untuk memenuhi kebutuhan hidup mereka sehari-hari. Tidak hanya itu, kebutuhan konsumtif mereka karena ketidakpuasan sehingga menimbulkan pemborosan menjadikan mereka melakukan tindak pidana korupsi tersebut. Pemberantasan tindak pidana korupsi sampai saat ini belum terlaksana secara optimal sehingga perlu ditingkatkan mengingat pemerintah dan penegak hukum telah menyadari hal tersebut.

Adapun menurut pasal 3 peraturan nomor 30 Tahun 2002 tentang KPK menyatakan bahwa KPK merupakan lembaga yang memiliki kewajiban serta wewenang yang berdiri sendiri hingga bebas dari perintah. Terdapat asas-asas di Pasal 5 UU No. 30 Tahun 2002 antara lain kepastian hukum, keterbukaan, akuntabilitas, proporsionalitas dan kepentingan umum. Sehingga, KPK mendapatkan perubahan besar dalam penanganan kasus tindak pidana korupsi di negara ini. Penerapan saksi mahkota (kroon getuige) yaitu membongkar kejahatan terorganisir dan sebagai hadiahnya dikeluarkan dari daftar terdaktersangka/ terdakwa dan dijadikan sebagai sanksi dalam perkara itu karena berhasil membongkar kejahatan terorganisir (Seno, 2009).

Saksi pelaku dan pelapor tindak pidana dalam mengungkap perkara pidana dan telah membantu penegak telah sepantasnya diberikan perlindungan hukum. Pengaturan tentang perlindungan saksi pelaku dan pelapor dalam undang-undang tindak pidana akan mendukung kerja keras dan ketegasan penegak hukum dalam hal kepentingan masyarakat dalam melindungi dan mengayomi penegakan hukum di Indonesia.

Hukum acara pidana di Indonesia telah mengakui eksistensi justice collaborator di Indonesia sebagai saksi mahkota sehingga pengungkapan kebenaran tindak pidana seorang saksi diajukan di persidangan, namun dalam penerapannya justice collaborator tidak diatur secara tegas dalam undangundang tersebut. Jupri (2018) menyatakan bahwa yang dilakukan terdakwa dalam perkara yang dilakukan merupakan lebih dari satu orang. Semua terdakwa di jadikan saksi silang mengingat arti pentingnya saksi yang merupakan kualifikasi senilai saksi mahkota. Negara Belanda dan Italia telah menerapkan justice collaborator yang diharapkan mampu membongkar kejahatan terorganisir yang imbalannya adalah dikeluarkan dari daftar terdakwa dan dinyatakan sebagai saksi menurut Andi Hamzah.

Pasal 185 Ayat (6) KUHAP, menyatakan Hakim harus benar-benar memperhatikan beberapa hal:

a. Kesesuaian keterangan saksi terhadap suatu perkara

b. keterangan saksi sesuai dengan alat bukti

c. Adanya keterangan tertentu digunakan oleh saksi

d. Kesusilaan saksi serta cara hidup dapat mempengaruhi kepercayaan dari keterangannya tersebut.

Eksistensi Justice Collaborator secara terperinci disebutkan sebagai berikut:

a. Peraturan Pemerintah Nomor 71 Tahun 2000 pada pasal 5 ayat (2) mengatur pemberian perlindungan berupa status hukum serta tetap diberi perlindungan mengenai rasa aman dalam proses peradilan salah satunya tahap pemeriksaan dalam proses penyelidikan \& penyidikan.

b. mengenai hak dan perlindungan bagi setiap saksi, pelapor dan saksi pelapor di UndangUndang Nomor 13 Tahun 2006 jo Undang-Undang Nomor 31 Tahun 2014 dan pada pasal 10 ayat 2 khususnya, jika saksi dianggap sebagai tersangka dapat di bebaskan dari tuntutan 
pidana dalam kasus yang sama jika terbukti bersalah sehingga pertimbangan hakim dalam kesaksiannya di penjatuhan pidana.

Tidak terdapat satu pun peraturan menjelaskan tentang saksi dan ditafsir bahwa saksi dalam hal ini yaitu pelaku tindak pidana yang sebagai saksi dimana ia tersebut telah membantu pihak berwenang untuk membeberkan perkara dilakukan, seperti:

1) Keterangan yang diberikan akan memberatkan terdakwa lainnya

2) Informasi yang diberikan yaitu baik yang sudah diungkapkan

3) maupun belum diungkapkan mengenai keberadaan barang atau alat bukti ataupun tersangka yang lain

4) Dampak diberikan berupa kontribusi kepada penegak hukum

5) Letak saksi sebagai pelaku dalam perkara tindak pidana yang sama.

Perlakuan dengan membuat pertanyaan-pertanyaan bersalah atau guilty plea yang akan mengurangi hukumannya terdapat dalam Pasal 10 Ayat 2 UU No 13 Tahun 2006 jo UU No 31 Tahun 2014 dalam praktik hukum di Indonesia. Peraturan bersama oleh Menteri Hukum \& HAM, Jaksa Agung, Kepala Kepolisian Republik Indonesia, Komisi Pemberantasan Korupsi dan LPSK yang pada dasarnya mengatur mengenai eksistensi dan pengaturan bagi pelapor, saksi pelapor \& saksi pelaku yang bekerjasama \& juga sebagai pedoman bagi penegak hukum dalam melaksanakan kerjasama \& kordinasi mengenai perlindungan mengenai hal tersebut dalam ketentuan Pasal 10 ayat (2) UU No 13 Tahun 2006 jo UU No 31 Tahun 2014 dalam praktik hukum di Negara Indonesia.

\section{Sanksi Pidana terhadap Saksi Pelaku yang Bekerjasama dalam Tindak Pidana Korupsi}

Pertimbangan hakim untuk menjatuhkan putusan terhadap saksi pelaku yang bekerjasama sangat menentukan bagaimana sanksi yang harus dijalani oleh pelaku. Pertimbangan hakim merupakan aspek penting dalam mewujudkan nilai dalam suatu putusan hakim yang mengandung keadilan dan manfaat oleh pihak yang bersangkutan. Hal yang termuat dalam pertimbangan hakim yaitu:

1) Pokok persoalan/ajaran-ajaran yang tidak disangka

2) Analisis hukum/yuridis mengenai fakta yang terbukti dalam persidangan terhadap segala aspek menyangkut semua.

Petitum penggungat harus menarik kesimpulan terbukti atau tidaknya dan dikabulkan atau tidak tuntutan dalam pertimbangan satu demi satu sehingga hakim dapat menentukan suatu amar putusan (Arto, 2004). Hakim dalam melakukan kegiatan/tindakan/menelaah tentang peristiwa terlebih dahulu sehingga dalam memberikan pertimbangan ataupun penilaian serta dalam menghubungkan dengan peraturan yang berlaku karena hukum menjadi pedoman untuk para hakim dalam menjalankan tugasnya.

Dalam UU No. 8 Tahun 1981 tentang KUHAP menimbulkan banyak perubahan fundamental terhadap cara penyelesaian perkara di Indonesia. Dalam UU Kekuasaan Kehakiman yaitu UU No 48 Tahun 2009 diatur tentang kedudukan para Hakim dalam menyelesaikan suatu perkara. Undangundang nomor 8 tahun 1981 juga telah diatur dalam pasal 184 mengenai alat bukti yang sah yang mempunyai kegunaan sangat penting dalam pengambilan keputusan bagi para hakim dalam memutus perkara tindak pidana meliputi keterangan ahli, keterangan surat, keterangan petunjuk dan keterangan dari terdakwa itu sendiri (Widayanti, 2019). Sedangkan pasal 1 angka 27 membahas mengenai keterangan saksi dan batasan keterangan saksi. Unsur-unsur dalam UU No. 20 Tahun 2001 terkait UU No 31 Tahun 1999 mengenai Pemberantasan Tindak Pidana Korupsi meliputi setiap orang memberikan janji/ sesuatu kepada penyelenggara negara dengan maksud berbuat sesuatu dalam jabatannya yang bertentangan dgn kewajiban \& perbuatannya berlanjut sehingga setiap orang mengacu pada siapa yang dijadikan terdakwa/ setiap subjek hukum dalam mempertanggungjawabkan perbuatan pidananya sebagaimana dijelaskan dalam pasal 1 butir 3 yang menjelaskan setiap orang juga termasuk korporasi.

Terhadap terdakwa tidak ada yang namanya alasan pemaaf dan alasan pembenar, jadi barang siapa yang melakukan suatu tindak pidana memang sudah seharusnya mempertanggungjawabkan perbuatannya tersebut.

1) Memberikan janji/sesuatu 
Unsur ini mengandung elemen yaitu memberikan suatu janji yang menyebutkan bahwa hal tersebut dapat dilakukan pelaku tindak pidana itu sendiri dan/pihak ketiga untuk kepentingan pelaku korupsi tersebut telah disebutkan dalam Pasal 5 Ayat 1 Huruf a.

2) Kepada Pemerintah

Dalam tentang penyelenggaraan Negara bebas dan bersih dari korupsi, kolusi dan nepotisme dalam UU No. 28 Tahun 1999 adalah pemerintah yang mempunyai fungsi dan tugas pokok terkait penyelenggara Negara sesuai dengan peraturan yang berlaku. Dan, telah dijabarkan dalam ketentuan pasal 2 UU No. 28 Tahun 1999 tentang siapa saja yang termasuk sebagai penyelenggara Negara.

3) Berbuat sesuatu dalam jabatannya yang bertentangan dengan kewajiban

Mengandung pengertian bahwa pejabat Negara/PNS dalam melaksanakan tugasnya dikatakan bertentangan dengan kewajiban jika penyelenggara tersebut berbuat sesuatu diluar dari tugasnya, penyelenggra Negara/PNS telah berbuat sesuatu tidak merupakan kewajibannya atau melekat dalam jabatannya sesuai dengan kewajiban yang melekat (Tahitu, 2015).

4) Perbuatan tersebut adalah perbuatan berlanjut

Adapun yang disebutkan dalam pengertian perbuatan berlanjut yaitu timbul dari niat kehendak dan keputusan, perbuatan yang jenisnya sama, waktu perbuatan tidak terlalu lama.

Dalam sema No. 4 Tahun 2011 disebutkan bahwa adalah seorang pelaku tindak pidana tertentu tetapi bukan pelaku utama sehingga penuntut umum dalam tuntutannya telah memberikan keterangan, bukti yang signifikan \& juga harus menyebutkan bahwa yang bersangkutan adalah seseorang yang menjadi Justice Collaborator.

Tujuan pemidanaan antara lain:

- Mencegah dilakukan tindak pidana dengan menegakan hukum demi masyarakat

- Mengadakan koreksi terhadap terdakwa

Pengertian hubungan dengan jabatan lebih luas bahwa pejabat adalah orang yang berwenang untuk melakukan jasa yang diminta tapi cukup bahwa jabatan itu memungkinkan untuk berbuat seperti itu (Hamzah, 2006). Teori-teori dalam pemidanaan terdapat 3 diantaranya:

a. Teori absolute

Pemidanaan berpegangan pada perilaku \& terletak pada terjadinya kejahatan itu sendiri. Sehingga teori ini memusatkan pada tindakan yang telah dilakukan serta mencari pendasaran dengan memandang ke masa lalu.

b. Teori relatif

Dalam teori yang bertujuan untuk mengubah sifat perilaku yang dilakukan oleh terdakwa dengan

melakukan pengawasan dan pembinaan sehingga kembali menlanjutkan kehidupannya.

c. Teori gabungan

Dalam point $9 \mathrm{c}$ telah diatur mengenai perlindungan hukum bagi Justice Collaborator, yaitu:

a) Menjatuhkan pidana percobaan bersyarat khusus

b) Menjatuhkan pidana paling ringan

c) Hakim harus mempertimbangkan rasa keadilan

Korupsi dan sanksi pidana disebutkan mulai pasal 2 sampai pasal 20 dan pada bab IV mulai pasal 25 sampai pasal 40 UU No 31 Tahun 1999 tentang ketentuan formil dalam menjalankan ketentuan meterilnya sehingga mengeluarkan UU No. 20 Tahun 2001 tentang Pemberantasan Tindak Pidana Korupsi dan pemerintah melakukan perubahan terhadap UU No 31 Tahun 1999 itu.

Menurut Muhammad Asri Irawan, semua tersangka yang ditangani oleh KPK berstatus Justice Collaborator dengan berkas tuntutan pidana dengan dimasukkan sebagai hal yang meringankan terdakwa (Jupri, 2018). Keberadaan dari teori Absolut dan Relatif, terciptanya teori gabungan menitik beratkan bahwa di salah satu unsurnya tanpa menghilangkan unsur lain / keseimbangan antara kedua unsur dan didasarkan untuk tujuan pembalasan dengan penerapan secara kombinasi menitik beratkan (R. Abdoel Djamali, 2005). Peraturan perundang-undangan tentang tindak pidana korupsi belum dilaksanakan secara konsisten serta mengingat pemberantasan korupsi yang memerlukan waktu yang tidak sedikit dikarenakan masalah korupsi tidak dapat ditangani secara instan.

Adapun Unsur-unsur dalam tindak pidana korupsi antara lain:

1) Perbuatan tersebut merupakan perbuatan yang melawan hukum

2) Perbuatan tersebut termasuk penyalahgunaan kewenangan

3) Akan merugikan keuangan Negara 
4) Hal untuk memperkaya diri sendiri

\section{SIMPULAN}

Justice Collaborator merupakan pelaku yang ikut dalam perkara pidana yang diungkapkannya tapi tidak merupakan pelaku berpengaruh besar dalam tindak pidana tersebut. Adapun peraturan yang mengatur mengenai korupsi yaitu Pasal 2 Peraturan No 31 Tahun 1999 terkait UU No 20 Tahun 2001 menyatakan bahwa korupsi mencakup perbuatan melanggar hukum yang mengatur dengan memperkaya diri sendiri dengan menggunakan keuangan perekonomian negara. Dalam hukum positif Indonesia terdapat peraturan tentang Justice Collaborator di Peraturan Pemerintah No. 71 Pasal 5 Ayat 2 Tahun 2000 mengatur mengenai hak serta perlindungan hukum bagi setiap saksi, pelapor tindak pidana/saksi yang melapor. Sedangkan pertimbangan hakim dalam menjatuhkan sanksi pidana terhadap justice collaborator dalam tindak pidana korupsi yang unsurnya berdasarkan UU No. 20 Tahun 2001 terkait UU No 31 Tahun 1999 mengenai Pemberantasan Perkara Korupsi serta terdapat dalam Surat Edaran Mahkamah Agung No 4 Tahun 2011 dalam tindakan khusus mengenai sanksi pidana yaitu memberikan keringanan bentuk perlindungan lain.

\section{DAFTAR PUSTAKA}

Arto, M. (2004). Praktek Perkara Perdata pada Pengadilan Agama (4th ed.). Pustaka Pelajar.

Hamzah, A. (2006). Pemberantasan Korupsi melalui Hukum Pidana Nasional \& Internasional. PT Radja Grafindo Persada.

Hartanti, E. (2009). Tindak Pidana Korupsi. Sinar Grafika.

Jupri. (2018). Reward Keringanan Sanksi Pidana bagi Justice Collaborator Perkara Korupsi. Jurnal Transformative, 4(1), 13-32.

Mulyadi, L. (2015). Perlindungan Hukum terhadap Whistleblower \& Justice Collaborator dalam Upaya Penanggulangan Organized Crime. Alumni.

Prodjohamidjojo, M. (2002). Hukum Perkawinan Indonesia. Indonesia Legal Center Publishing.

Seno, A. I. (2009). Korupsi dan Penegakan Hukum. Diadit.

Tahitu, G. Z. (2015). Keberadaan Saksi Mahkota dalam Sistem Peradilan Pidana Indonesia. Lex Crimen, 4(1), 164-178.

Widayanti, Y. (2019). Analisis Yuridis tentang Pembuktian Dakwaan dengan Saksi-Saksi yang Dibacakan oleh Penuntut Umum dalam Pemeriksaan Perkara Penggelapan dalam Jabatan (Studi Putusan Pengadilan Negeri Jakarta Pusat Nomor: 1182/Pid.B/2014/PN.Jkt.Pst.). Jurnal Verstek, 5(3), 199-213. 